\title{
Mapping Modernism: Gaining in Translation - Martinus Nijhoff and T. S. Eliot
}

\author{
THEO D'HAEN
}

This article appeared in 2009 as "Mapping Modernism: Gaining in Translation Martinus Nijhoff and T.S. Eliot," in Comparative Critical Studies 6, 1, 21-41, and in a translation by César Domínguez as "Cartografiando el Modernismo: ganando con la traducción. Martinus Nijhoff y T.S. Eliot," in Literatura europea comparada, César Domínguez, ed. Madrid : Arco/Libros, 2009, pp. 287-312. When citing please refer to the published versions.

\section{Gaining in Translation}

A number of recent attempts to reconfigure comparative literature have been concerned with upgrading the role played by translation in the drawing and re-drawing of the literary world map. ${ }^{1}$ In one way or another this is a basic premise at the heart of Susan Bassnett's Comparative Literature: A Critical Introduction, Franco Moretti's Atlas of the European Novel: 1800-1900, David Damrosch's What is World Literature?, and Emily Apter's The Translation Zone. ${ }^{2}$ The present article is meant as a small contribution to this ongoing debate. Specifically, I want to focus on the role of translation played in the œuvre of the man who is today considered the greatest Dutch Modernist poet, Martinus Nijhoff (1894-1953). As with his fellow-Modernists Adriaan Roland Holst (1888-1976) and J. J. Slauerhoff (1898-1936), Nijhoff's translational activities have been consistently construed as merely ancillary to his 'creative' activities. In reality, I think their translational activities functioned as agents of change for the latter.

Of the three Dutch authors mentioned, Roland Holst stayed within the narrowest translational bounds, translating from English only, and exclusively from the works of W. B. Yeats. His case is also clearest as regards the relationship between his activities as a translator and his creative work. ${ }^{3}$ Estimations of the precise impact of Slauerhoff's translations from the French, Spanish, and classical Chinese on his own creative practice vary considerably. ${ }^{4}$ Nijhoff translated a lot, mostly from the French, German and English. Wiljan van den Akker and Gillis Dorleijn, when discussing Nijhoff's working methods in the Commentary section of Volume Two of their three-volume 1993 Critical Edition of Nijhoff's Gedichten (Poems), insist on the importance translation held for Nijhoff; ${ }^{5}$ however, they do not systematically link the shifts in Nijhoff's poetry and poetics to his translational activities. We notice a similar pattern with other critics. Here therefore I would like to hazard at least the possibility of such a link, and investigate this possibility with specific reference to T. S. Eliot.

\section{A Matter of 'Affinity'}


The Dutch writer and essayist Theun de Vries, in a 1954 Nijhoff memorial volume, laments the fact that late in his life the Dutch poet had engaged in translating T. S. Eliot's verse play The Cocktail Party, a translation that was published in 1951. For De Vries, Nijhoff's interest in the exercise was purely technical and had nothing to do with the theme of the play. As De Vries puts it: 'Nijhoff [interesseerde] zich hier [...] voor een vormprobleem, waarbij hij de - barbaarse - inhoud van het stuk bijkomstig achtte: de technische vaardigheid, welke de overdracht van het gesproken Engelse woord in ditto Nederlands vereiste' (Nijhoff was interested in a problem of form here, next to which he thought the - barbaric - content of the play coincidental: the technical skill required to render spoken English into equivalent Dutch). ${ }^{6}$ De Vries writes from a specific position, inspired by the Marxist politics he adhered to in those days, that makes the particular orientation of Eliot's play hard to swallow for him. However, the implication of De Vries' remarks goes beyond his own parochial politics or world view. He seems to suggest that Nijhoff's translation of Eliot's play is nothing but a stylistic exercise, unrelated to Nijhoff's own creative work because of what De Vries perceives as the obvious lack of correlation between the subject matter, the 'thematics' if you will, of the two poets. Regardless of the specific world view held by other Dutch commentators on Nijhoff, De Vries's opinion as to the tangentiality of Nijhoff's Eliot translations to the former's original work has been widely shared. Consequently, the relationship between the two poets has mostly been dubbed as one of kinship, of affiliation, rather than 'filiation'.

In fact, the relationship of Nijhoff's poetry to that of T. S. Eliot has been a recurrent point of discussion in Dutch criticism. A. L. Sötemann, one of the most distinguished scholars of modern Dutch literature, in a 1976 article commenting on Nijhoff and Eliot, remarks that Dirk W. Dijkhuis, in an article entitled 'Nijhoff en Eliot/Eliot en Nijhoff', 'was able to point out a number of remarkable parallels between the two poets whose first books were published at about the same time'. ${ }^{8}$ Still, Sötemann immediately rejects the possibility that Nijhoff might have been influenced by his Anglo-American counterpart. Sötemann explains the 'remarkable parallels between the two poets' from a common poetical ancestry in the work of Charles Baudelaire and Jules Laforgue. Moreover, he argues, 'it is reasonably certain that Nijhoff came to know Eliot's work rather late in his career'. ${ }^{9}$ Even if, as Sötemann mentions in a footnote, 'about 1950, Nijhoff told J. Kamerbeek Jr. [another Dutch scholar and critic, TD]: "Shortly after the First World War we discovered that Eliot was an important poet", Sötemann hastens to add that 'more than half of the poems which constitute Nijhoff's Vormen (1924), however, had already been published, when Nijhoff discovered Eliot'. ${ }^{10}$ He concludes: 'consequently there would be hardly any possibility of direct influence, even less so as the striking parallels are to be found in Nijhoff's earlier poetry'. ${ }^{11}$ Eliot's first volume of poetry, Prufrock and Other Observations, supposedly containing the verse to which Sötemann sees Nijhoff's own early verse as closest to, appeared in 1917. Nijhoff's own first collection of poetry, De Wandelaar, had already appeared in 1916. If furthermore we accept, as we must, the dating of Nijhoff's poems in de Verzamelde Gedichten (Collected Poems) as edited by W. J. van den Akker and G. J. Dorleijn in 2001, ${ }^{12}$ based on their diplomatic three-volume 1993 edition of Nijhoff's poems (but not his plays, nor any of his prose) in the Monumenta Literaria Neerlandica, and correlate this with Nijhoff's own dating of his first acquaintance with the work of Eliot's work as 'shortly after' the First World War, indeed more than half of the poems in Vormen, and of course all of De Wandelaar, as well as a number of poems that remained uncollected, 
and sometimes unpublished, until (sometimes much) later, pre-date any possible such acquaintance. Unless of course the Dutch poet knew Eliot's early poetry from separate and earlier publications in Little Magazines such as the Harvard Advocate, Blast, Others, or Poetry, where poems by Eliot had been appearing since well before the First World War. Here detailed biographical research is called for, including research as to whether any one, or more, of these magazines were available anywhere in the Netherlands, or abroad, where Nijhoff might have had access to them. One would also like to know how 'shortly' after the First World War Nijhoff read Eliot. Or whether he had any other means of access to the early work of Eliot. Unfortunately, no detailed biography has yet appeared on Nijhoff.

When it comes to the later Nijhoff and Eliot, Sötemann quotes Nijhoff's own remark, from a lecture the latter gave on his work, and particularly on the genesis of what is generally agreed to be his supreme achievement, the long poem Awater, from Nieuwe Gedichten (1934), in Enschede in 1935, and published posthumously, that 'I had no examples $[\ldots]$ the ingenious early poetry of the French poet Jean Cocteau did something for me, as did the work of the American T.S. Eliot [...] but these poets, other than the surrealists, had not held their trade, their métier, in sufficiently high esteem [...] in their search for abstraction and community they had smashed their own poetical forms as if of glass'. ${ }^{13}$ Sötemann concludes that Nijhoff 'in principle [...] had to conduct the search by his own light'. ${ }^{14}$ Accordingly, in his subsequent summary and discussion of Awater Sötemann never mentions Eliot again. This is all the more surprising given the terms he uses to describe the poem. Its subject is said to be 'the quest for a traveling companion through the hell, the desert of the modern city, from which, consequently, the verbal material is taken'. ${ }^{15}$ Its technique is said to involve 'three complicating elements': 'a number of cultural references, both scriptural and literary', 'a subtle interlacing of familiar expressions and complicated, refined sentence structures', ${ }^{16}$ and the creation of - in the formulation of James L. Kugel from his The Techniques of Strangeness in Symbolist Poetry ${ }^{17}$ - 'strangeness by not telling everything, or, more precisely, by implying that not everything has been told'. ${ }^{18}$ Surely this resembles nothing so much as Eliot's The Waste Land (1922).

To convey to the reader at least some of the flavour of Awater, I quote two passages from English translations, the first from the 1954 version by Daan van der Vat, and the second from the 1961 translation by James S. Holmes:

Ik heb een man gezien. Hij heeft geen naam.

Geef hem ons aller vóórnaam bij elkaar.

Hij is de zoon van een vrouw en een vader.

Zodra de rode zon is opgegaan

gaat hij de stad in. Hij komt langs mijn raam.

De avond blauwt, hij komt er weer vandaan.

Hij werkt op een kantoor, heet daar Awater.

Zie hem, hij is bekleed met kemelhaar

geregen door een naald. Zijn lijf is mager

gespijsd met welt wilde honing en sprinkhanen.

(I saw a man, a man that bears no name,

let our joint Christian names encompass him,

Some father's son born from some mother's womb. 
When rosy dawn incarnadines the East, he passes by my window towards the town not to return until the evening dusk.

He is a clerk. Awater he is called by fellow-clerks. Behold him as he goes. The hair of camels, threaded through the eyes of needles, clothes his body. He is lean, because he feeds on locusts and wild honey.) ${ }^{19}$

Vanavond volg ik dus Awater's spoor, ik kijk de kat, zo zegt men, uit de boom, en morgen, gaat het goed, stel ik mij voor. Zo sta ik bij de hoge stoep. Ik schroom. Het slaat half-zes. De tijd wordt eindeloos. De straat wordt door voorbijgangers doorstroomd. In elke schaduw wordt een licht ontstoken, makend, al dwalend, omtrekken in rook.

(Tonight, then, I'll pursue Awater's trail;

I'll watch to see which way the cat will jump, as people say, and then if all goes well, tomorrow I will introduce myself.

So here I stand, beside the entryway. I'm filled with qualms. A clock strikes half-past five.

Time has a stop. Wayfarers flood the streets.

In every shadow is a light ignited

that in its wanderings shapes contours in smoke. $)^{20}$

Other critics have explicitly linked The Waste Land and Awater. This is for instance the case with Luc Wenseleers (1966) ${ }^{21}$ and Karel Meeuwesse (1967), ${ }^{22}$ even though both insist that James Joyce's Ulysses was a much more important source for the structure and the main character of Awater. The traditional view on Eliot and Nijhoff is summed up by R. P. Meijer in his 1971 Literature of the Low Countries:

In Awater Nijhoff appears as a poet of the type to which also T. S. Eliot belonged: the poet who was no longer a romantic Bohemian, nor a recluse of the ivory tower, but a man among men. It is significant that when Nijhoff first planned the writing of Awater, he intended to model the main character on [the Dutch poet, TD] Potgieter, who in the nineteenth century was the prototype of the poet as an ordinary man. Significantly also, Eliot was with Cocteau the only poet whom Nijhoff mentioned as having been of any help when he wrote Awater, and if one wants to place Nijhoff in his European context, Eliot was his next of kin. Both poets may be called traditionbound modernists, both were reformers rather than revolutionaries. Nijhoff acknowledged his affinity to Eliot by translating several of his poems and The Cocktail Party, but it is no simple matter to assess accurately to what extent Nijhoff's own poetry was influenced by Eliot. One can point to some stylistic parallels, or to a common tendency to give ironic treatment to romantic attributes of the past, but there is little evidence of any direct influence. As for the most striking parallel between 
their work, i.e. the remarkably successful use of the vocabulary and rhythms of everyday speech, it is more likely that Nijhoff was building on the foundations laid by such poets as Gorter, Dèr Mouw and Bloem than that he was following Eliot. Another point of contact between Nijhoff and Eliot is the fact that both make considerable demands on their readers. Awater may not be quite as cryptic as The Waste Land, but it is a far from easy poem with its oblique references to the Bible, Joyce's Ulysses and the Parcival Legend. ${ }^{23}$

Again, we see Meijer almost casually dismissing the Eliot translations as immaterial to Nijhoff's own poetical development. In what follows I want to take issue with this customary critical practice and argue at least the possibility that instead of being immaterial to the development of Nijhoff's poetry and poetics, a mere matter of affinity, as it were, these translations were fundamental to and instrumental for the formation of the latter. I want to do so in the context of what others have called, respectively, Nijhoff's 'creative impasse', his habit of 'creative imitation', and his 'creative rivalry' with (near)-contemporaries.

\section{Nijhoff's 'Creative Crises'}

Critical opinion differs as to where Nijhoff belongs in terms of his 'poetics': whether with the 'classicists' or the 'modernists', or - as Van den Akker puts it in his Dichter in het grensgebied: over de poëzie van $M$. Nijhoff in de jaren dertig - modern and traditional at the same time ('modern en traditioneel tegelijk'). ${ }^{24}$ As corroboration Van den Akker points to Ton Anbeek's well-known Geschiedenis van de Nederlandse literatuur 1885-1985 (1990). Anbeek devotes a separate chapter (pp. 134-147) to Nijhoff, he says, 'not only to underline the latter's importance, but also to allow his poetry and poetics to play a transitional role' in Dutch poetry. ${ }^{25}$ Van den Akker himself reads Nijhoff's own 1926 statement 'ik wil niet tot een kamp behoren, maar tot de poëzie' (I do not want to side with any party, but with poetry) as one element allowing us to range him with the modernists. In particular, this statement would point to the attitude of 'doubt' that Douwe Fokkema and Elrud Ibsch, in Het Modernisme in de Europese Letterkunde, see as constitutive of European Modernism. ${ }^{26}$

Taking his cue from Fokkema and Ibsch, but also from Van den Akker's Een dichter schreit niet: de poetica van M. Nijhoff, ${ }^{27}$ Dorleijn, in his 1989 Terug naar de auteur: over M. Nijhoff, discussing the period leading up to and beyond the publication of Nijhoff's collection Vormen in 1924, argues that

I am firmly convinced that Nijhoff, notwithstanding his tone of assurance, did not know exactly where he stood. He sides with a certain party and later distances himself again from it, he defends a certain point of view and later, usually implicitly, attacks that same point of view. It is just as easy to recognize in this see-sawing the attitude of a doubtful 'modernist' (in the sense of Fokkema and Ibsch), trying out a number of positions to subsequently renounce them, as that of a young writer looking for a personal point of view. ${ }^{28}$

Dorleijn contends that Nijhoff during the entire period concerned went through some sort of 'creative impasse' or 'creative crisis'. ${ }^{29}$ The poet was obviously looking for examples, both in his immediate environment and in the world of literature at large. 
In Nijhoff's immediate environment the most obvious candidate for emulation was Adriaan Roland Holst. Slightly older than Nijhoff himself, Roland Holst had made a great reputation for himself with his early poetry. Van den Akker quotes a letter Nijhoff wrote to a friend in reaction to the proofs he received of a rather wavering review, in the authoritative periodical De Gids, by the well-known Dutch author and critic P. N. van Eyck, of Vormen. Roland Holst served as poetry editor for this leading Dutch literary magazine. Nijhoff complains: 'it made me feel down [...] you'll all agree with him [Van Eyck], and the only one who will stick with me is Jany [Adriaan Roland Holst], in this spiritual hibernation' ${ }^{30}$ Indeed, as Dorleijn points out, Nijhoff for some of his poems borrowed the vocabulary of Roland Holst. This is particularly the case in 'Zwerver en elven,' the last in a series of five poems Nijhoff published in De Gids of January 1924. As Dorleijn puts it: 'In Zwerver en elven [Vagabond and Elves] Nijhoff seems to have distilled all that is typical for Roland Holst in Voorbij de wegen [Beyond Roads] (1920), the collection that established Roland Holst's reputation as the leading poet of his generation'. ${ }^{31}$ Still, Nijhoff did not just imitate Roland Holst. In fact, Dorleijn warns, Nijhoff's line 'Niets, niets is op de wegen vooruit' (Nothing, nothing goes beyond roads) in Zwerver en elven might well be read as a 'polemical reference to the title of Roland Holst's collection'; thus, 'all things considered, this poem situates itself in the tradition of Roland Holst, but even more so over against that tradition' ${ }^{32}$ Dorleijn concludes that, if there is 'admiration' ('bewondering'), there is also 'creative rivalry' ('creatieve wedijver'). Kees Fens, a leading literary critic of Dutch literature in the second half of the twentieth century, already in 1967 had used the same term to refer to the relation of Nijhoff to Roland Holst. ${ }^{33}$ But in this same article Fens also points to the resemblance between the early poetry of Nijhoff and that of Eliot.

'Creatieve wedijver', or creative rivalry, is also the term Van den Akker uses to describe the relationship obtaining between Nijhoff's Awater and Eliot's The Waste Land. ${ }^{34}$ Van den Akker points out a possible verbal echo from Eliot's 'fragments [...] shared against my ruins' in Nijhoff's 'puinhopen' (heaps of rubble, or 'ruins'!) from the beginning of Awater. ${ }^{35} \mathrm{He}$ also identifies a number of structural parallels: a game of chess features in both works, as do reminiscences of the grail legend, and there are the shared motifs of the woman, the desert, the city, and water. Even if Van den Akker argues that with Nijhoff all these things are 'volkomen anders geprojecteerd' (completely differently oriented), ${ }^{36}$ the titles of the poems do themselves already indicate the rivalry or opposition obtaining between them, as Van den Akker notes: the Waste LAND versus '[A]WATER' ('het (Waste) LAND versus het (A)WATER'). ${ }^{37}$ Still, Van den Akker also makes a very convincing case for considering the character of Awater in Nijhoff's eponymous poem to be an only thinly disguised portrait of T. S. Eliot himself. In other words, with the Nijhoff of Nieuwe Gedichten, and particularly Awater, we notice an ambiguity with regard to Eliot such as we saw before with regard to Roland Holst. In fact, the entire first 'stanza' (if such we can call it) of Awater reads like an implicit dialogue with Eliot's The Waste Land where Nijhoff insists that, in Van der Vat's translation, 'this work, which out of chaos rising / appears as void and formless as the earth', does not 'like a former age of song, / glorify ruins, sing of sun or skies,' and that 'foundation stones have hardly found their beds' ${ }^{38}$ or, in Holmes's translation, 'its aim is not, as in a previous age / to see the rubble heaps and sing fair skies, / for song is but the passion of a fester, / never rubble, whatever else it was. / A first stone's barely lowered in place'. ${ }^{39}$

In his 1976 article Sötemann warned that 'retrospective statements of poets should 
in general be treated with reserve, and particularly those of Nijhoff, who delighted in playing the elusive Pimpernel'. ${ }^{40}$ Van den Akker, a pupil of Sötemann's, and the latter's successor to the Chair of Modern Dutch Literature at Utrecht University, takes his former mentor's remark to heart when in a discussion of Nijhoff's 1935 Enschede lecture he opines that 'sometimes what is not being said says more than what is'. ${ }^{41}$ Nijhoff lists four modernist prose writers as having provided him with ammunition for Awater: Proust, Lawrence, Virginia Woolf, and Joyce. Of the four, Joyce receives the slightest mention. Yet, Van den Akker notes, and as has been almost exhaustively argued by many another critic, it is undoubtedly Ulysses (1922) that is most conspicuously present in Nijhoff's poem.

In similar fashion, Van den Akker feels that the reason Nijhoff gives for disclaiming Eliot's work as an 'example' for Awater, viz. that the Anglo-American poet would have shunned traditional verse forms, is spurious. After all, Van den Akker objects, as early as 1917 Eliot had already rejected so-called free verse, and his 1919 essay 'Tradition and the Individual Talent' stressed the continuity of classical forms. Further, the resemblance between the two works is thematic rather than structural. In short, Van den Akker concludes, 'the parallels between the discursive poetics of Eliot and Nijhoff are such that I think it a greater challenge to prove that Nijhoff was not aware of Eliot's statements than the other way around'. ${ }^{42}$

Sometimes it almost seems as if Nijhoff went out of his way to avoid any suggestion as to a possible direct link between his own work and that of his AngloAmerican colleague. As Van den Akker puts it:

In 1935 Nijhoff was well acquainted with Eliot's work, the text of the lecture leaves no doubt about that. But if we disregard this manuscript - after all the poet himself never went public with it - the reader of the collected essays and reviews cannot but conclude that Nijhoff came very late to the work of his Anglo-American colleague. The latter's name only crops up once in more than a thousand pages of this part of the Collected Works, in a review of The Cocktail Party of 1952, one year before Nijhoff's death, when his best work lay far behind him. Here again the adage seems true that what is not being said must be of importance. ${ }^{43}$

In fact, as Van den Akker already suggested in his 1985 dissertation Een dichter schreit niet: de poetica van M. Nijhoff, the Dutch poet in nothing so much resembles his AngloAmerican colleague as precisely in this continued reticence about seminal influences. ${ }^{44}$ It is my contention, therefore - and I will illustrate this below -that what is not being said in this particular case may at least partially be revealed in and through the translational activity of Nijhoff.

\section{Nijhoff as Translator}

Volume Three of Nijhoff's Verzameld Werk, first published in 1982, gathers all his translations known until then. ${ }^{45}$ Some of these appeared during Nijhoff's lifetime, others were published only posthumously. Among the former we find De geschiedenis van den soldaat (after Histoire du Soldat of Igor Strawinsky and C. F. Ramuz), which first appeared in De Gids in 1926, De storm (after Shakespeare's The Tempest), first appearance in De Gids in 1928, Moer (after André Gide's Paludes), first published in the periodical De Stem in 1929, Het verhaal van den vos (after Ramuz's adaptation, 
Renard, histoire burlesque, etc. of Strawinsky's original), published in 1933, Ifigeneia in Taurië (after Euripides' Iphigeneia in Tauris), published in 1951 but already begun in 1936, De cocktailparty (after T. S. Eliot's The Cocktail Party), published in 1951. A translation of Menander's Het Scheidsgerecht (Epitrepontes) remained unfinished at Nijhoff's death.

Among the shorter published translations there are two songs by Hugo Wolff, both published in 1925, and one poem each by Jean de La Fontaine, published in 1927, Heinrich Heine, 1932, Charles d'Orléans, 1943, Alfred de Musset, Alfred de Vigny, Victor Hugo, Gérard de Nerval, all 1944, Nicholas G. Lély, published posthumously in 1954 but already done in 1947, eleven pieces from Edgar Lee Masters' Spoon River Anthology, all published posthumously in the literary periodical Maatstaf in 1954, and seven psalms from the Bible, also published posthumously in the same number of Maatstaf, which is a Nijhoff memorial issue. There are also three published translations of poems by T. S. Eliot, all of them published in 1950 in De Gids: 'De Hippopotamus', 'De hartekreet van J. Alfred Prufrock' ('The Love Song of J. Alfred Prufrock'), and 'Hoe onbehaaglijk het is Mr Eliot te ontmoeten' ('Lines for Cuscuscaraway and Mirza Murad Ali Beg'). The unpublished shorter pieces included in the Verzameld Werk number two poems by Charles Baudelaire, 'De reis van de drie koningen' (after 'Journey of the Magi' by T. S. Eliot), a Provençal carol, a song by Léon Xanrof, and a Swedish lullaby. The notes to the various translations mention that among the papers left at Nijhoff's death there was also a partially completed version of another poem by Baudelaire, as well as preliminary drafts of translations of (parts of) The Family Reunion and The Rock (part of Choruses from 'The Rock') by T. S. Eliot.

The 1993 Van den Akker and Dorleijn Critical Edition of Nijhoff's poems, $M$. Nijhoff: Gedichten, adds to the poet's works a number of pieces unpublished until then. Amongst these figure a translation of Oscar Wilde's The Ballad of Reading Goal, rendered as 'Tuchthuis-Ballade', and dating from as early as 1912, done in collaboration with Victor van Vriesland, a noted Dutch poet in his own right. There is also a translation of section I of 'Burnt Norton' from the Four Quartets. Nijhoff's translations from Eliot, then, both published and unpublished, cover the complete span of the AngloAmerican poet's career, and the entire range of the latter's production: from the early 'The Hippopotamus' and 'The Love Song of J. Alfred Prufrock', both from Prufrock (1917), over 'Journey of the Magi' (1927), 'Lines upon Cuscuscaraway and Mirza Murad Ali Beg' from the 'Five-Finger Exercises' (1933), passages from 'Burnt Norton' (1935, the first of the Four Quartets), The Rock (1934) and The Family Reunion (1939), to the late The Cocktail Party (1949). There is also no other poet from whom Nijhoff translated as much as from Eliot.

The notes to Nijhoff's translations in Volume Three of the Verzameld Werk (1982) indicate that among the books he owned at his death in 1953 there was a Penguin edition of the Selected Poems of T. S. Eliot. Folded into this volume there were several pages of hand-written notes by Nijhoff, among others from F. O. Matthiessen's 1935 The Achievement of T. S. Eliot, as well as a list of publications on Eliot from 1947 and 1948. This leads the editor of this part of the Verzameld Werk, Gerrit Kamphuis, to the conclusion that Nijhoff used the Selected Poems mentioned as the basis for his Eliot translations. More in general, Kamphuis posits that 'Nijhoff became particularly engrossed in the work of Eliot in the period 1945-1950'. ${ }^{46}$ Van den Akker and Dorleijn apparently concur with Kamphuis when in Volume Two of the Commentary of their Critical Edition they suggest that Nijhoff, in order to prepare for the translation of The 
Cocktail Party, 'once more went through the complete oeuvre of Eliot and also studied recent work on the Anglo-American author. Among the papers he left at his death there are some sheets with notes on Eliot. It is at this time too that he will have translated some poems by Eliot'. ${ }^{47}$ Consequently, in Volume Three of their Critical Edition 'Apparaat' (Critical Apparatus) - Van den Akker and Dorleijn confidently list '1949/prior to July 1950' ('1949/voor juli 1950') for all Eliot translations except 'De Reis der Drie Koningen' ('Journey of the Magi'), for which they put down 'probably 1949' ('waarschijnlijk 1949'). In a footnote Van den Akker and Dorleijn add though that Nijhoff had already commented upon this poem in 1939, and that already then he apparently knew it well. Note also their hedging use of 'zal' ('will have' in the sense of 'must have') in Volume Two of their Critical Commentary. In fact, neither Kamphuis (1982) nor Van den Akker and Dorleijn (1993) date the manuscripts of Nijhoff's Eliot translations on the basis of precise material indicators. For various reasons, I would want to argue that in fact there is considerable room for doubt as to the dates concerned.

\section{How Pleasant to Meet Mr Nijhoff}

To begin with, Kamphuis, while suggesting that Nijhoff seems to have been particularly occupied with Eliot's work in the latter half of the 1940s, feels compelled to add: 'although in his Enschede lecture of 1935 he shows that he knew it already then' ${ }^{48}$ Of course, as the Enschede lecture remained, once again, unpublished during Nijhoff's lifetime, his early acquaintance with the work of Eliot remained, at least publicly, largely suppressed. In fact, as we saw before, Nijhoff knew the work of Eliot from right after the First World War. Given that he regularly travelled to England during the first years after the First World War - Dorleijn quotes Nijhoff writing to Constant van Wessem on 5 December 1919: 'I only returned from England last Monday' ${ }^{49}$ - nothing even prevents Nijhoff actually having picked up a copy of Prufrock already then.

Second, as mentioned earlier too, if we look at the sheer bulk of Nijhoff's translations, there is no other poet from whom he translated as much, and as variedly, as from Eliot. Some of these translations remained unpublished during the Dutch poet's lifetime. Others were published very late in Nijhoff's life. However, might we not 'translate' Van den Akker's remarks about the importance of 'what is not said' in Nijhoff's critical statements to the realm of his translations, in the sense that what is not published says more about examples and influences than what is? Sötemann saw Baudelaire as the prime influence upon Nijhoff. On the basis of the hand-writing of the manuscripts of Nijhoff's Baudelaire translations Kamphuis dates these to (probably) 1925. Yet, they too remained unpublished during Nijhoff's lifetime. From the dates of Nijhoff's published translations, we know that the 1920s were a busy period for him in this regard. However, with the exception of De Storm, a translation of Shakespeare's The Tempest, there seem to be no translations from English in this period. From a review Nijhoff wrote in 1925, it is clear that he knew English and American poetry quite well already early in his career. ${ }^{50}$ In this review he mentions Edgar Lee Masters. Nijhoff's translations from this American poet's work would appear only posthumously, though. Finally, already in 1912 Nijhoff (with a friend) had translated Wilde's Ballad of Reading Goal, and from the 1928 De Storm we know that Nijhoff in the period concerned could produce superb translations from the English.

Third, even though the manuscript of 'Hoe onbehaaglijk het is Mr Eliot te ontmoeten' was among the pages folded into the 1948 Eliot Selected Poems, the Eliot 
original, 'Lines from Cuscuscaraway and Mirza Murad Ali Beg', does not figure in this edition. Of other translations, such as 'De hippopotamus', no manuscript was found, even though the original does figure in the Selected Poems in question The exact relationship between this particular Selected Poems and Nijhoff's Eliot translations therefore seems far from clear to me. The manuscript of 'Hoe onbehaaglijk het is $\mathrm{Mr}$ Eliot te ontmoeten' figuring among the pages folded into Nijhoff's copy of the 1948 Eliot Selected Poems, in which the original in question, 'Lines for Cuscuscaraway and Mirza Murad Ali Beg', does not figure, is sufficient proof that Nijhoff had access to other editions of Eliot's work.

Fourth, in the absence of firm material indicators permitting their precise dating, Nijhoff's notes from Matthiessen and his list of critical materials on Eliot, along with some manuscript translations from Eliot, being folded into the 1948 Eliot Selected Poems that Nijhoff owned is no guarantee that these materials actually date from 1948 or later. Nijhoff may well have gathered everything he could find on Eliot, new material as well as notes and translations he may have had around for a long time already perhaps, when receiving the commission to translate The Cocktailparty. As De cocktailparty was a commissioned translation, there could be no suspicion of spontaneous 'influence'. Once the names Nijhoff and Eliot had been publicly linked in this way anyway, there could be no more harm in publishing further translations from the same poet - hence the publication of 'De hippopotamus', 'De hartekreet van J. Alfred Prufrock' en 'Hoe onbehaaglijk het is Mr Eliot te ontmoeten'. Given the dates of their eventual publication, moreover, these translations were almost sure to be seen as indications of a certain retrospective 'affinity' with Eliot on the part of Nijhoff, rather than as proof of any previous and long-ranging influence of Eliot's on Nijhoff's own poetic practice. However, these may well have been translations that Nijhoff had had around for years, either in the form they were published eventually, or in previous drafts.

In sum, then, given all this it seems not improbable that Nijhoff may have at least tried his hand at translating Eliot well before 1935, and certainly before 1948. Just as in the 1920s he did some translations from Baudelaire which he never published, he may very well have made translations from Eliot which only much later found their way into print, or that actually were never published during Nijhoff's lifetime. Nijhoff may have had various reasons for not 'going public' with such translations at the time, but one reason may well have been that also suggested by Van den Akker for Nijhoff's not mentioning Eliot in his critical writings, and for leaving the Enschede lecture in which he does mention the Anglo-American poet likewise unpublished.

How then do I see the relationship between Nijhoff's poetry and his translations from Eliot? What I want to suggest is that it is the actual practice of translation from Eliot that tided Nijhoff over the 'creative impasse' that Dorleijn notes. ${ }^{51}$ Specifically, my suggestion is that, just as Roland Holst via his early translations of Yeats sought to get out from under the shadow of Herman Gorter, one of the most popular and highly esteemed Dutch poets of the turn of the twentieth century and a family friend of the Roland Holsts, thus initiating a life-long creative dialogue with the Irish poet's work, so Nijhoff in the 1930s definitively turned to Eliot to get out from under the shadow of Roland Holst, and to from then on continue a life-long dialogue with the work of his Anglo-American counterpart, and that he did so via translation. As mentioned before, Kees Fens in his 1967 article on "Het Veer" van M. Nijhoff' ("The Ferry" by M. Nijhoff') sees Nijhoff as first associating himself with, and then turning away from, Roland Holst in the movement from Part I to Part II of 'Het Veer', one of the early 
poems from Nieuwe Gedichten. Van den Akker and Dorleijn (Critical Edition, Volume Three) date 'Het Veer' to 1930. The last poem in Nieuwe Gedichten is Awater, which Van den Akker and Dorleijn date to 1933/1934. It is this poem that for Van den Akker (Dichter in het grensgebied) and most other commentators marks Nijhoff's definitive turn toward Eliot. Now the original of 'Hoe onbehaaglijk het is Mr Eliot te ontmoeten', the manuscript translation found folded into the 1948 copy of Eliot's Selected Poems found in the estate of Nijhoff at the latter's death in 1954, namely 'Lines for Cuscuscaraway and Mirza Murad Ali Beg', was published not long before Awater, and practically provides a thumbnail sketch of the man who according to Van den Akker is the subject of this most celebrated of Nijhoff's poems, that is to say: Eliot himself. ${ }^{52}$ Nijhoff, as far as we know, and unless some hitherto unknown manuscript turning up would prove otherwise, never ventured upon translating The Waste Land itself. The relation between The Waste Land and Awater, then, is oblique rather than direct, and situates itself on the level of verbal echoes and responses, such as I suggested we find in the first lines of 'Awater' with regard to The Waste Land. However, I see a possible translation of 'Lines from Cuscuscaraway and Mirza Murad Ali Beg' as having served as a sort of five-finger exercise for Awater - of course, Eliot's poem itself is part of a five-poem sequence entitled, not unimportantly so in the given context I think, 'FiveFinger Exercises', and published in January 1933. The Flemish critic Willy Spillebeen, author of a detailed and influential study of one of Nijhoff's best-known shorter poems, 'Het steenen kindje' (The Stone Child), explicitly links what he calls Nijhoff's method of 'creative imitation' to the Dutch poet's penchant for translation when he remarks

That Nijhoff in the middle part [of Awater, TD] practiced 'creative imitation' and uses amongst other devices the structure of James Joyce's Ulysses as well as a number of traditional symbols from Ulysses and T. S. Eliot's The Waste Land to picture Awater's wanderings with the I-speaker of the poem in tow, has of course to do with the fact that he was much more highly gifted technically than creatively. [...] Such 'creative imitation' is strongly present in his later work, especially in his mystery plays, but also in his increased devotion to translation. He was always in search of a 'subject' and found it even more readily than before in the work of others. $^{53}$

In a comparable way, early translations of 'The Journey of the Magi', 'Burnt Norton', The Rock, and The Family Reunion, works that mark Eliot's turn towards overtly religiously inspired poetry and verse-plays, may have set Nijhoff' on his way toward his own three similarly inspired verse-plays of the 1940s, De ster van Bethlehem, De dag des Heren en Des Heilands tuin (The Star of Bethlehem, The Day of the Lord, and The Savior's Garden). These three plays were collected and published as Het Heilige Hout in 1950, a title that echoes Eliot's 1920 collection of essays, The Sacred Wood. In his brief introduction to Het Heilige Hout Nijhoff himself insists that he received the inspiration for the playlets from his mother, who served in the Salvation Army, and wrote passion plays for youthful audiences. The verse form he uses in these plays he says to have derived from his translation of Euripides's Iphigeneia in Tauris, which he rendered as Ifigeneia in Taurië. Surely though in spirit these plays are close to Eliot's verse plays, and to his later poetry.

There is not room enough here to go into much detail about Nijhoff's late plays, but here at least are the first lines of De ster van Bethlehem as spoken by two guardian 
angels - in my rough English translation following the original I have not tried to catch Nijhoff's rhythms, nor his rhymes:

De ster straalt die Gods aantocht meldt. -

Wij zijn als wacht hier opgesteld. -

Beneden ons ligt in het veld

het vredig dorpje Bethlehem. -

Ginds is de stad Jeruzalem.

Daar troont, - gedachten kwellen hem, -

Herodes, t' hoofd steunt in zijn hand.

Stil. - Ik hoor aan Bethlehems kant

dorpsvrouwen spreken op het land. ${ }^{54}$

(The star shines that announces the coming of our Lord.-

We are standing here as guardians. -

Beneath us in the fields

Lies peaceful Bethlehem. -

Beyond is the city of Jerusalem.

There on his throne, - haunted by his thoughts, -

Herodes sits, his head in his hand.

Quiet. - I hear from Bethlehem

village women speaking in the fields.)

Of course, it is always possible that I am totally wrong, and that Kamphuis, and Van den Akker and Dorleijn after him, are entirely correct in limiting Nijhoff's translational fervour for Eliot to the period 1946-1950, and hence to the run-up to what is and remains Nijhoff's best-known Eliot translation, viz. De cocktailparty of 1951. But then why do the hand-written pages in the 1948 Penguin Eliot Selected Poems contain notes only from the 1935 Matthiessen monograph on Eliot, and merely list a number of more recent books and articles on Eliot? Does not this suggest that the Matthiessen notes are much older, perhaps from the period immediately following the book's publication, and that Nijhoff, while he did get around to compiling a list of newer work on Eliot never actually went to the trouble of reading it, let alone making notes? When was this list compiled anyway? Previous to Nijhoff's start on the - commissioned - translation of The Cocktailparty? Or only subsequently? Perhaps a Critical Edition of Nijhoff's plays and prose, complementing Van den Akker and Dorlijn's Critical Edition of the poems, might shed some light here.

Mapping Modernism

Does all this make Nijhoff come out a much diminished poet? Surely not. After all, Eliot himself in his early poems borrowed freely from French examples, and James E. Miller Jr. in his recent T. S. Eliot: The Making of an American Poet makes a good case for The Waste Land being at least partially modelled upon André Gide's 1896 Paludes. ${ }^{55}$ In fact, for a very long stretch in European literary history translation of admired predecessors or colleagues was the first step on the arduous road to literary eminence, the second and third steps being imitation and emulation. The difference lies in that before Romanticism it was quite alright, even honourable, to admit such poetic apprenticeship. 
In our century, though, originality has been the conditio sine qua non for literary greatness. That is why writers like to picture themselves as self-born heroes, and why critics and literary historians - particularly when patriotically inspired - prefer to paint them in the same light.

In the 1954 Daamen and Van Oorschot Nijhoff memorial volume Martinus Nijhoff, Gerrit Kamphuis, the editor of both Volume One (original poetry) and Volume Three (translations) of Nijhoff's Verzameld Werk, briefly discusses Nijhoff's poetry as an instance of the trend toward depersonalisation in modern poetry best exemplified in the work of T. S. Eliot. He concludes that this 'makes [Nijhoff] take part in an international development of the human spirit, not by imitating foreign examples, as has so often been the case in the course of Dutch literature, but by a development clearly resulting from his own personal evolution'. ${ }^{56}$

Earlier, we saw that Sötemann, writing twenty years after Kamphuis, was still largely of the latter's opinion. Another twenty years on, Van den Akker, after an illuminating comparison between Nijhoff's Awater and T. S. Eliot's The Waste Land, proposes that 'Nijhoff's poetry can be understood better, or to put it more prudently and correctly, more fully if we hold it against the light of international modernism'. ${ }^{57}$ It is my contention that a detailed study of Nijhoff's translational activities could contribute substantially toward such a fuller understanding. In fact, I believe that such an approach would permit us to situate Dutch Modernism more accurately in the general literary and cultural flows of the first half of the twentieth century. Specifically, it would permit us to do so, not, as hitherto has been mostly the case, by simply comparing Dutch Modernist works to their foreign counterparts in terms of themes, techniques, or world views, but in terms of actual relations. Some of this work has already been done piecemeal. However, what we do not have is a systematic exploration of the issue covering all, or at least all major, Dutch-language Modernists. Needless to say, a similar exercise could be usefully undertaken not only for other authors, but also other literatures and other languages. Such a mapping of translational activities and relationships, if undertaken in a systematic manner across linguistic boundaries, could contribute crucially to the development of yet another 'atlas', in the sense employed and practised by Franco Moretti, but this time of literary Modernism.

\section{NOTES}

1 This is a much revised and considerably extended version of an essay that appeared as 'Lost in Translation? Nijhoff and Eliot' in Under Construction, Links for the Site of Literary Theory: Essays in Honor of Hendrik van Gorp, edited by Dirk de Geest, Dirk Delabastita and others (Leuven: Leuven University Press, 2000), pp. 225-238. I am grateful to the editors for permission to re-use passages from the earlier version.

2 Susan Bassnett, Comparative Literature: A Critical Introduction (Oxford: Blackwell, 1993); Franco Moretti, Atlas of the European Novel, 1800-1900 (London: Verso, 1998); David Damrosch, What is World Literature? (Princeton, NJ: Princeton University Press, 2003); Emily Apter, The Translation Zone: A New Comparative Literature, (Princeton: Princeton University Press, 2006).

3 Theo D'haen, 'W. B. Yeats and Roland Holst: (S)Elective Affinities', Yeats: An Annual of Critical and Textual Studies 8 (1990), 49-70; Theo D'haen, 'De mythe A. Roland Holst', Literatuur 7:4 (1990), 194-202; Theo D'haen, 'Yeats in the Dutch-language Countries', in The Reception of Yeats in Europe, edited by K. P. S. Jochum (London and New York: Thoemmes Continuum, 2006), pp. $12-24$. 
4 Anton van Duinkerken, 'Slauerhoff en Samain', De Gemeenschap 17:5 (1941), 283-286, also in Er bleef toch geen bewijs: Opstellen over de poëzie van J. Slauerhoff, Edited and collected by Dirk Kroon ('S Gravenhage: BZZTôH, 1982), pp. 172-75; Hendrik de Vries, 'Slauerhoffs vertalingen uit het Spaansch I-IV, 'Criterium 6 (1948), 87-89, 232-238, 379-383, 477-482, also in Kroon, Er bleef toch geen bewijs, pp. 196-213; R. P. Meijer, 'Slauerhoffs Chinese bewerkingen en hun Engelse voorbeelden', De Gids 118:5 (1955), 355-363, also in Kroon, Er bleef toch geen bewijs, pp. 225-234; Klaas Ruitenbeek, 'Slauerhoffs Yoeng Poe Tsjoeng in de Europese letterkunde', Literatuur 2:1 (1985), 2-10; Arie Pos, Cheng Shaogang and Nanneke Scheltens-Boerma, Dronken in de lente (Leiden: Barabinsk, 1993).

5 Wiljan van den Akker and Gillis J. Dorleijn, M. Nijhoff: Gedichten. Historisch-kritische uitgave, Monumenta Literaria Neerlandica, VII, 1, 2 and 3 (Assen and Maastricht: Van Gorcum, for the Koninklijke Nederlandse Akademie van Wetenschappen, 1993).

6 Theun de Vries, 'Nijhoff's experiment,' in Martinus Nijhoff (Den Haag and Amsterdam: Daamen N. V. and G. A. van Oorschot, 1954), pp. 104-112; this quotation p. 111.

7 Published in Merlyn 2:6 (1963-1964), 1-24.

8 A. L Sötemann, "Non-spectacular" Modernism: Martinus Nijhoff's Poetry in its European Context', in Nijhoff, Van Ostaijen, 'De Stijl': Modernism in the Netherlands and Belgium in the First Quarter of the 20th Century. Six Essays, edited by Francis Bulhof (The Hague: Martinus Nijhoff, 1976), pp. 95-116; this quote p. 102.

9 Sötemann, “'Non-spectacular” Modernism', p. 102.

10 Ibid.

11 Ibid.

12 Martinus Nijhoff, Verzamelde Gedichten, edited by Wiljan van den Akker and Gilles J. Dorleijn (Amsterdam: Bert Bakker, 2001).

13 Martinus Nijhoff, Verzameld Werk, II: kritisch, verhalend en nagelaten proza, Volumes II.1 and II.2 (Den Haag and Amsterdam: Bert Bakker and G. A. van Oorschot, 1961), 1166-1167; 'voorbeelden had ik niet [...] ik had iets aan de geniale jeugdverzen van Jean Cocteau, de Franse dichter, en aan de Amerikaan T. S. Eliot [...] maar dezen hadden, in tegenstelling tot de surrealisten, hun métier, hun vak, te gering geacht [...] zij hadden op zoek naar abstractie en menigte, hun versvorm zelf als ruiten ingeslagen'.

14 Sötemann, “'Non-spectacular” Modernism', p. 111.

15 Ibid., p. 113.

16 Ibid.

17 James L. Kugel, The Techniques of Strangeness in Symbolist Poetry (New Haven and London: Yale University Press, 1971), p. 38. [[the relationship of the source in footnote 17 and 18 is not clear here; are you quoting Kugel directly from his book, or from Sötemann? Can this be clarified?]] I am quoting Sötemann here, who is quoting Kugel ...

18 Sötemann, “"Non-spectacular” Modernism', p. 114.

19 Daan van der Vat, 'Awater in het Engels,' De Gids 117:2 (1954), 110-24. Also in Nooit zag ik Awater zo van nabij: Interpretaties van een gedicht. Teksten omtrent Awater van Martinus Nijhoff. Bijeengebracht door Dirk Kroon ('S Gravenhage: BZZTôH, 1981), pp. 49-55.

20 James S. Holmes, 'Awater by Martinus Nijhoff', Delta 4:2 (1961). Also in Kroon, Nooit zag ik Awater zo van nabij, pp. 56-62.

21 Luc Wenseleers, "'Awater", in Het wonderbaarlijk lichaam: Martinus Nijhoff en de moderne westerse poëzie (Den Haag: Bert Bakker/Daamen, 1966), pp. 158-228. Also in Kroon, Nooit zag ik Awater zo van nabij, pp. 77-134.

22 Karel Meeuwesse, 'Aantekeningen bij Awater', De Nieuwe Taalgids 60:1 (1967), 33-41 and 60:3 (1967), 171-76. Also in Kroon, Nooit zag ik Awater zo van nabij, pp. 149-66.

${ }^{23}$ R. P. Meijer, Literature of the Low Countries: A Short History of Dutch Literature in the Netherlands and Belgium (Assen: Van Gorcum, 1971), p. 302.

24 Wiljan van den Akker, Dichter in het grensgebied: over de poëzie van M. Nijhoff in de jaren dertig (Amsterdam: Bert Bakker, 1994), p. 48.

25 This is a quotation from Wiljan van den Akker, Dichter in het grensgebied: over de poëzie van M. Nijhoff in de jaren dertig (Amsterdam: Bert Bakker, 1994), p. 48 discussing how Ton Anbeek treats 
Nijhoff in Ton Anbeek, Geschiedenis van de Nederlandse literatuur 1885-1985 (Amsterdam: De Arbeiderspers, 1990); 'niet alleen om diens belang te accentueren, maar ook om diens poëzie en poëzie-opvattingen als een overgangsgebied te laten fungeren'.

26 Douwe Fokkema and Elrud Ibsch, Het modernisme in de Europese letterkunde (Amsterdam: De Arbeiderspers, 1984).

27 Wiljan van den Akker, Een dichter schreit niet: de poetica van M. Nijhoff, 2 vols (Utrecht: Veen, 1985).

28 G. J. Dorleijn, Terug naar de auteur: over M. Nijhoff (Baarn: de Prom, 1989), p. 62, note 16.

'Het is mijn stellige overtuiging dat Nijhoff, ondanks zijn zekere toon, niet precies wist waar hij stond. Hij sluit zich bij sommigen aan om zich daarna weer van hen te distantiëren, hij verdedigt een standpunt om het later, meestal impliciet, te bestrijden. Men kan in die wisseling van meningen evengoed de houding van een twijfelende 'modernist' (in de zin van Fokkema en Ibsch) herkennen, die allerlei standpunten beproeft om ze daarna weer op te geven, als die van de jonge schrijver op zoek naar een standpunt.'

29 Ibid., p. 34.

30 Akker, Dichter in het grensgebied, p. 50; 'ik was er down van [...] jullie zullen het allemaal met hem eens zijn, en ik blijf met Jany alleen over, in deze geestelijke overwintering'. [[please check that this page reference is correct, since I brought a couple of things together in your text.]] Correct!

31 Dorleijn, Terug naar de auteur, p. 15; 'Nijhoff lijkt van 'Zwerver en elven' een soort destillaat gemaakt te hebben van Holstiana uit Voorbij de wegen (1920), de bundel die definitief Roland Holsts naam vestigde als grootste dichter van zijn generatie'.

32 Ibid., p. 17; 'polemische referentie aan de titel van Roland Holsts bundel', 'met dit al neemt het gedicht een positie in in het verlengde van, maar meer nog tegenover, het dichterschap van Roland Holst'.

33 Kees Fens, "'Het Veer" van M. Nijhoff', in Jaarboek van de Maatschapij der Nederlandse Letterkunde te Leiden, 1966-1967 (Leiden: E. J. Brill, 1968), pp. 27-44.

34 Akker, Dichter in het grensgebied, p. 39.

35 Ibid.

36 Ibid.

37 Ibid, p. 40.

38 Van der Vat, in Kroon, Nooit zag ik Awater, p. 49.

39 Holmes, in Kroon, Nooit zag ik Awater, p. 56.

40 Sötemann, “Non-spectacular” Modernism', p. 102.

41 Van den Akker, Dichter in het grensgebied, p. 35; 'wat verzwegen wordt, zegt soms meer dan wat wordt meegedeeld'.

42 Ibid., p. 37; 'er zijn zulke grote overeenkomsten tussen de poëticale uitspraken van Eliot en Nijhoff, dat het me een grotere uitdaging lijkt om aan te tonen dat Nijhoff diens beschouwingen niet dan wel heeft gekend'.

43 Dichter in het grensgebied, p. 37; 'Nijhoff was in 1935 vertrouwd met Eliot, daar valt niet aan te twijfelen getuige de tekst van de lezing. Maar wanneer we dit manuscript buiten beschouwing laten - de dichter heeft het tenslotte zelf nooit openbaar gemaakt - dan zou de lezer van zijn verzamelde essays en kritieken moeilijk een andere conclusie kunnen trekken dan dat hij zijn AmerikaansEngelse collega pas heel laat heeft leren kennen. Diens naam komt op de meer dan duizend pagina's, die dit deel van het Verzameld Werk beslaat, slechts eenmaal voor en wel in een recensie van De cocktailparty uit 1952, één jaar voor Nijhoffs dood, toen zijn hoogtepunt allang voorbij was. Alweer lijkt hier te gelden: wat verzwegen wordt, moet wel van betekenis zijn'.

44 Wiljan van den Akker, Een dichter schreit niet, vol. 1, p. 25 and vol. 2, p. 19, note 74.

45 Martinus Nijhoff, Verzameld Werk, vol. 3: vertalingen [[further down, as regards vol. 1, you write Verzamelde Gedichten in upper case: should this read Vertalingen?]] (Amsterdam: Bert Bakker, 1982). Yes! Upper Case, zo Vertalingen.

46 Nijhoff, Verzameld Werk, vol. 3, p. 603; 'Nijhoff heeft zich omstreeks 1946/'50 bijzonder in het werk van Eliot verdiept'.

47 Wiljan van den Akker and Gillis J. Dorleijn, M. Nijhoff: Gedichten, vol. 2, p. 400; 'het hele oeuvre van Eliot weer eens [heeft] doorgenomen en ook recente literatuur over de Anglo-Amerikaanse auteur [heeft] bestudeerd. In zijn nalatenschap bevinden zich enkele blocnotevellen met aantekeningen van 
deze Eliotlectuur. In deze tijd zal hij ook enkele gedichten van Eliot hebben vertaald'.

48 Nijhoff, Verzameld Werk, vol. 3, p. 603; 'hoewel hij dit ook in '35 reeds blijkt te kennen gezien zijn lezing over eigen werk te Enschede in dat jaar'.

49 Dorleijn, Terug naar de auteur, p. 64, note 38; 'ik ben dezen maandag pas uit England teruggekeerd'.

50 Nijhoff, Verzameld Werk, vol. 2, p. 292.

51 Dorleijn, Terug naar de auteur, p. 34.

52 Van den Akker, Dichter in het grensgebied, p. 41.

53 Willy Spillebeen, 'Awater: aanvaarding van de evolutie en de geschiedenis', in De geboorte van het stenen kindje: thematische analyse van het scheppend werk van Martinus Nijhoff (Nijmegen: Gottmer and Brugge: Orion, 1977), pp. 201-246. Also in Kroon, Nooit zag ik Awater zo van nabij, pp. 273-305, this quotation p. 277; 'Dat Nijhoff in het middenstuk [van Awater, TD] aan 'creatieve imitatio' heeft gedaan en o.a. [...] gedeeltelijk het stramien van Ulysses van James Joyce en ook heel wat traditionele symbolen uit Ulysses en The Waste Land van T.S. Eliot aanwendt om Awaters zwerftocht met de ik-persoon in zijn spoor weer te geven, heeft natuurlijk te maken met zijn veel grotere technische dan creatieve begaafdheid. [...] Dergelijke 'creatieve imitatio' komt sterk tot uiting in zijn later werk, in zijn lekespelen vooral, maar ook in de toegespitste aandacht op vertaalwerk. Hij was inderdaad aldoor op zoek naar een 'onderwerp' en vond dit laatste nóg vaker dan vroeger in het werk van anderen'.

54 Verzameld Werk, vol. 1: Verzamelde Gedichten, p. 262.

55 James E. Miller Jr., T. S. Eliot: The Making of an American Poet, 1888-1922 (University Park, PA: Pennsylvania State University Press, 2005), p. 126-127.

56 Gerrit Kamphuis, 'Nijhoff op weg naar een nieuwe tijd', in Martinus Nijhoff (s.l.: Daamen N.V./G.A. Van Oorschot, 1954), pp. 68-72, this quote p. 72; 'doet [Nijhoff] deel hebben aan een internationale ontwikkeling van de menselijke geest, niet door navolging van buitenlandse voorbeelden, zoals die in de geschiedenis van de Nederlandse letteren zo dikwijls is te constateren, maar door een ontwikkeling, die duidelijk resulteert uit de opeenvolging van zijn persoonlijke verworvenheden'.

57 Van den Akker, Dichter in het grensgebied, p. 41; 'Nijhoff's poëzie kan beter, of voorzichtiger en juister uitgedrukt, rijker worden begrepen wanneer zij tegen het licht van het internationale modernisme wordt gehouden'. 